\title{
Synthesis, Experimental and Theoretical Characterization of Bidentate 5-Nitro-2-(Pyridin-2-Yl)-1H-Benzo[D] Imidazole Ligand and its Pd (II) Complex
}

\author{
A. Akbari", Z. Bakhte-ei \\ Science Department, Payame Noor University, 19395-4697 Tehran, I. R. of Iran \\ *Corresponding Author: a akbari@pnu.ac.ir
}

Copyright (C) 2013 Horizon Research Publishing All rights reserved.

\begin{abstract}
In this work, we report a combined experimental and theoretical study on the molecular structure and electronic and vibrational spectra of 5-nitro-2-(pyridin-2-yl)-1H-benzo[d] imidazole ligand, npbi, and its $\mathrm{Pd}(\mathrm{II})$ complex, which coordinating atoms of npbi is the imine and pyridine nitrogens. The nature of npbi and its complex were determined by IR an UV-Vis spectroscopy. The theoretical results obtained by performing DFT calculations, using the ADF 2009 package, compared with experimental results. The optimized geometric bond lengths and bond angles of npbi and its complex confirmed the complexation. The CHN data analysis confirmed the suggested structure of complex too.
\end{abstract}

Keywords Palladium, Benzimidazole, Pyridine, ADF

\section{Introduction}

Palladium coordination compounds are very important materials. They are reviewed as anti-viral, anti-fungal, anti-microbial and anti-tumor agents on not too many years ago [1]. The acyclic tridentate quinoline-2-carboxaldehyde-2-pyridylhydrazone ligand has used for synthesizing of a luminescent palladium(II) complex, which exhibits DNA binding activities and induces apoptosis in human prostate cancer cells [2]. Synthesis, spectral, electrochemical, DFT studies and evaluation of biological activity of $\mathrm{Pd}(\mathrm{II})$ and $\mathrm{Pt}(\mathrm{II})$ complexes of $\mathrm{N}, \mathrm{N}$-donor benzimidazole ligand is reported, which showed poor activity against the investigated bacteria in comparison with the free ligand [3] or no specific antimicrobial activity[4]. The worthy advantage of this report is about introducing of the synthesized ligand as a determining reagent for $\mathrm{Pd}(\mathrm{II})$ in the presence of other noble metal ions. The antimicrobial and antitumor activity of some $\mathrm{Pd}(\mathrm{II})$ complexes containing quinolinylaminophosphonates is reported reportedis reported Novel metal complexes containing palladium has reported with promising chemotherapeutic potential and different mechanisms in comparison platinum drugs [5]. Synthesis and structures of palladium (II) complexes containing pyrazole and thiocyanate ligands [6], and their thermal decomposition reported in the literature [7]. Synthesis, application or DFT studies of some other complexes of palladium (II) containing various Schiff bases ligand show the importance of this kind of compounds in chemistry world[8-12].

In the present work, cis-dichloro (5-nitro-2-(pyridin-2-yl)-1H-benzimidazole palladium(II) complex was synthesized and the IR or UV spectroscopy techniques were used to validate its structure.

In addition, the molecular geometry and vibration spectra of npbi and its complex were calculated by applying density functional theory (DFT) computations and then compared with obtained experimental results.

\section{Experimental and calculations}

\subsection{Synthesis of Npbi Ligand}

The ligand was synthesized similar to reported procedures $[13,14]$. Picolinic acid (1.2g) and 1,2-diamino 4-nitro benzene $(1.07 \mathrm{~g})$ were added to $14 \mathrm{~g}$ polyphosphoric acid, and stirred under $\mathrm{N}_{2}$ at $160^{\circ} \mathrm{C}$ for $8 \mathrm{~h}$. The resulting viscous solution was poured into $250 \mathrm{ml} \mathrm{H}_{2} \mathrm{O}$, producing a tan solid which was collected by suction filtration. The residue was then suspended in $250 \mathrm{ml}$ of aqueous $0.5 \mathrm{M} \mathrm{Na}_{2} \mathrm{CO}_{3}$, and filtered giving a pale yellow powder. Recrystallization from methanol /water caused as a fine yellow solid. $\left(\mathrm{mp}: 213^{\circ} \mathrm{C}\right.$, conductivity: $1.800 \Omega^{-1} \mathrm{~cm}^{2} \mathrm{~mol}^{-1}$ )

\subsection{Synthesis of $\mathrm{Pd}(\mathrm{Npbi}) \mathrm{Cl}_{2}$ Complex}

One 1:1 ratio of $\mathrm{PdCl}_{2}$ and npbi ligand calculated stoichiometry relation and then weighted. $\mathrm{PdCl}_{2}(0.1 \mathrm{mmol})$ was dissolved in $10 \mathrm{ml}$ of ethanol after stirring for $1 \mathrm{~h}$. The 
resulting brown solution was added drop wise to npbi solution $(0.1 \mathrm{mmol}$ in $5 \mathrm{ml}$ of ethanol). Then the mixture was stirred for $72 \mathrm{~h}$. The green solid filtered, washed with ethanol $(3 * 5 \mathrm{ml})$ and dried at vacuum. (mp: $145^{\circ} \mathrm{C}$ (decomposed), conductivity: $\left.12.5 \Omega^{-1} \mathrm{~cm}^{2} \mathrm{~mol}^{-1}\right)$, $\mathrm{CHN}$ analysis data: $\mathrm{Cal}: \mathrm{C}, 34.52$; H, 1.93 ; N,13.42; Found : C, $34.41 ; \mathrm{H}, 1.86 ; \mathrm{N}, 12.32$

\subsection{Physical Methods}

IR spectra of the ligand and platinum complex were obtained as $\mathrm{KBr}$ pellets and were recorded with using a Shimadzu 8400 FT-IR spectrometer in the $4000-400 \mathrm{~cm}^{-1}$ region. The electronic spectra was recorded in DMF using a Shimadzu 2500 UV-Vis spectrometer. Conductivity measurements were done using Herisau Metrohm CH6101 conductometer.

\subsection{Computational methods}

The molecular structure of the 5-nitro-2-(pyridin-2-yl)-1H-benzo[d] imidazole ligand(npbi) was optimized by a DFT method at LDA, BLYP, OLYP levels and $\mathrm{DZ}, \mathrm{DZP}, \mathrm{TZ}_{2} \mathrm{P}$ basis sets, all with using the ADF package. This optimization was done for $\left[\mathrm{Pd}(\mathrm{npbi}) \mathrm{Cl}_{2}\right]$ complex at OLYP as a selected level and DZ, DZP, $\mathrm{TZ}_{2} \mathrm{P}$ basis sets. The vibrational frequencies of ligand and its $\mathrm{Pd}(\mathrm{II})$ complex were calculated at preferred OLYP level.

\section{Results and Discussion}

\subsection{Geometry Optimization}

Optimized structures of npbi ligand and its $\mathrm{Pd}(\mathrm{II})$ complex with labeling of the atoms are shown in Figs.1.
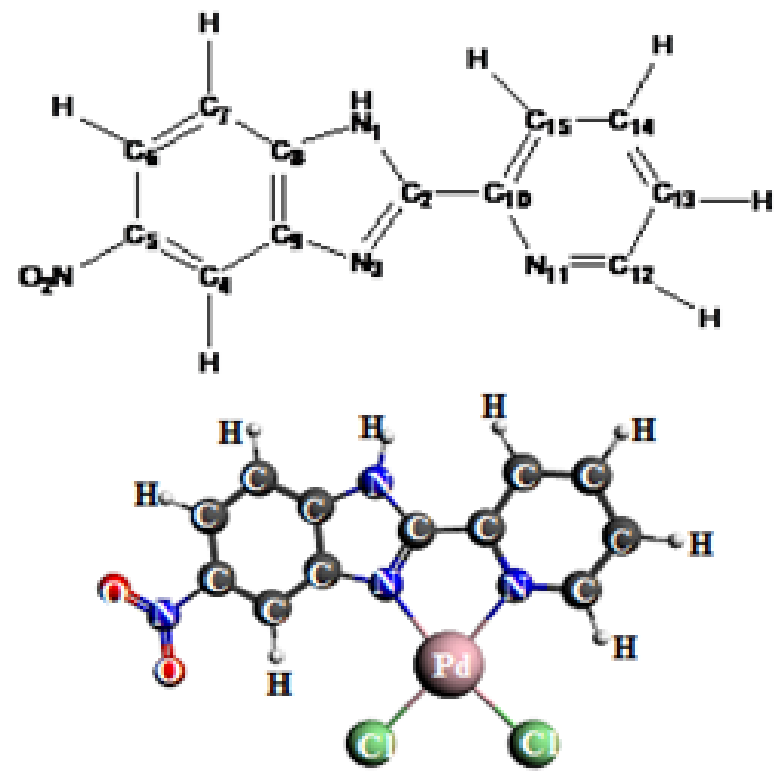

Figure 1. Structure of npbi ligand and OLYP optimized geometry of related Pd complex with their labeling.
There is a very well agreement between the theoretically calculated geometric parameters of npbi ligand and the x-ray diffraction data of related or similar structures such as 2-methylbenzimidazole and 2-picoline, available in the literature $[15,16]$.

The experimental and optimized structural parameters of npbi ligand calculated at OLYP level with DZ, DZP.TZ2P basis sets are listed in Table 1.

According to our calculations, all the bond lengths and angles of npbi ligand are in good agreement with the experimental values of similar structures. For example, the $\mathrm{N}_{1}-\mathrm{C}_{8}$ and $\mathrm{C}_{12}-\mathrm{N}_{11}$ bond lengths, also the $\mathrm{N}_{1}-\mathrm{C}_{2}-\mathrm{N}_{3}$ angle is $1.383,1.332$ and 112.7 respectively, both in calculation or $\mathrm{X}$-ray data. These data are underlined in Table 1.

The geometric parameters of $\left[\mathrm{Pd}(\mathrm{npbi}) \mathrm{CL}_{2}\right]$ complex are compared with $\mathrm{x}$-ray diffraction data available for cis-dichloro-(2-pyridin-benzimidazole) palladium (II) complex[17]. As one can see, there is a very well agreement between these data. The optimized geometric parameters of Pd(II) complex calculated by OLYP with DZ, DZP. TZ2P basis sets are listed in Table 2 .

Theoretical angle values of pd(II) complex have some deviation from square-planer geometry. For example the calculated angles $\mathrm{N}_{3}-\mathrm{Pd}-\mathrm{Cl}_{2}$ and $\mathrm{N}_{11}-\mathrm{Pd}-\mathrm{Cl}_{1}$ obtained $171.5^{\circ}$ and $175.3^{\circ}$ respectively instead of $180^{\circ}$.

\subsection{Chemistry}

The new npbi ligand and its $\mathrm{Pd}(\mathrm{II})$ complex were characterized by spectrochemical data (UV-Vis, FTIR), conductivity and microanalysis measurements.

\subsubsection{Uv. Vis Spectroscopy / Electronic Spectra}

A strong absorption band is observed at $280 \mathrm{~nm}$ for free npbi ligand spectrum could be assigned to the $n \rightarrow \pi^{*}$ intra ligand transitions[18,19]. After the formation of $\operatorname{Pd}(\mathrm{II})$ complex, this absorption is undergoed a red shift, which leads to appearance of a more intense band than ligand for $\mathrm{n} \rightarrow \pi^{*}$ transitions at $284.8 \mathrm{~nm}$. The low energy of this transition could be due to coordination of nitrogen atoms of npbi ligand to the palladium center. As we will see later; the calculated shapes and orbital distribution confirm this kind of charge transferring.

Furthermore, in the electronic spectrum of Pd (II) complex, the observed absorption at $369.2 \mathrm{~nm}$ in the UV region could be assigned to metal to ligand charge transfer [20].

\subsubsection{HOMO and LUMO Energy Levels}

During the optimization at the mentioned level and basis sets, the energy levels for the highest occupied molecular orbital (HOMO) and lowest unoccupied molecular orbital (LUMO) of $\left[\mathrm{Pd}(\mathrm{npbi}) \mathrm{Cl}_{2}\right]$ complex are calculated. The HOMO energy calculated in DZ, DZP and TZ2P basis set are $-5.763,-5.591$ and -5.117 respectively. The LUMO energy for the same trend is calculated as $-4.840,-4.323$ and -4.323 .

Although these results are similar but choosing the DZ basis set is shown a little more negative level of the energy 
both for the HOMO and LUMO. Furthermore, the differences between these two important levels, gap, which could be considered in electronic transitions, are 0.923, 1.268 and 1.371 respectively. It means that the gap is more when calculated using TZ2P basis set.
The energy of other orbitals in all cases are calculated too. For example, the $\mathrm{MO}$ diagram of energy for $\left[\mathrm{Pd}(\mathrm{npbi}) \mathrm{Cl}_{2}\right]$ complex, calculated at OLYP level and DZ basis set is shown in Figs.2.

Table 1. Selected geometry parameters of ${ }^{\mathrm{a}} \mathrm{npbi},{ }^{\mathrm{b}} \mathrm{mb},{ }^{\mathrm{c}} \mathrm{pic},{ }^{\mathrm{d}} \mathrm{Pd}(\mathrm{n})$ and ${ }^{\mathrm{e}} \mathrm{Pd}(\mathrm{p})$

\begin{tabular}{|c|c|c|c|c|c|c|c|c|c|}
\hline \multirow[b]{2}{*}{ fB.L. $\left(\mathrm{A}^{\circ}\right)$} & \multirow{2}{*}{$\begin{array}{l}\text { a mb } \\
\text { X-ray }\end{array}$} & \multirow{2}{*}{$\begin{array}{l}\text { b pic } \\
\text { X-ray }\end{array}$} & \multicolumn{3}{|c|}{ npbi (calculated) } & \multirow{2}{*}{$\begin{array}{l}\mathrm{dPd}(\mathrm{p}) \\
\text { X-ray }\end{array}$} & \multicolumn{3}{|c|}{$\mathrm{cPd}(\mathrm{n})($ calculated $)$} \\
\hline & & & $\mathrm{DZ}$ & DZP & $\mathrm{TZ2P}$ & & $\mathrm{DZ}$ & DZP & TZ2P \\
\hline $\mathrm{N} 1-\mathrm{C} 2$ & 1.335 & & 1.407 & 1.383 & 1.389 & - & 1.386 & 1.366 & 1.386 \\
\hline $\mathrm{C} 2-\mathrm{N} 3$ & 1.339 & & 1.333 & 1.310 & 1.314 & - & 1.345 & 1.322 & 1.344 \\
\hline N3-C9 & 1.389 & & 1.406 & 1.375 & 1.378 & - & 1.400 & 1.378 & 1.400 \\
\hline $\mathrm{C} 9-\mathrm{C} 8$ & 1.395 & & 1.422 & 1.412 & 1.418 & - & 1.420 & 1.409 & 1.420 \\
\hline $\mathrm{N} 1-\mathrm{C} 8$ & 1.383 & & 1.383 & 1.367 & 1.370 & - & 1.388 & 1.369 & 1.388 \\
\hline $\mathrm{C} 9-\mathrm{C} 4$ & 1.379 & - & 1.392 & 1.388 & 1.396 & - & 1.395 & 1.389 & 1.396 \\
\hline $\mathrm{C} 4-\mathrm{C} 5$ & 1.382 & - & 1.394 & 1.383 & 1.391 & - & 1.391 & 1.381 & 1.391 \\
\hline $\mathrm{C} 5-\mathrm{C} 6$ & 1.395 & - & 1.414 & 1.402 & 1.409 & - & 1.413 & 1.402 & 1.413 \\
\hline $\mathrm{C} 6-\mathrm{C} 7$ & 1.360 & - & 1.390 & 1.381 & 1.385 & - & 1.389 & 1.379 & 1.389 \\
\hline C7-C8 & 1.389 & - & 1.400 & 1.390 & 1.396 & - & 1.398 & 1.389 & 1.398 \\
\hline $\mathrm{C} 10-\mathrm{C} 15$ & - & - & 1.405 & 1.397 & 1.403 & - & 1.401 & 1.393 & 1.401 \\
\hline $\mathrm{C} 15-\mathrm{C} 14$ & - & - & 1.399 & 1.387 & 1.391 & - & 1.397 & 1.386 & 1.397 \\
\hline $\mathrm{C} 14-\mathrm{C} 13$ & - & - & 1.399 & 1.387 & 1.391 & - & 1.399 & 1.388 & 1.399 \\
\hline $\mathrm{C} 13-\mathrm{C} 12$ & - & - & 1.400 & 1.392 & 1.396 & - & 1.398 & 1.389 & 1.398 \\
\hline C12-N11 & - & $\overline{3} 00$ & 1.355 & 1.331 & 1.332 & - & 1.352 & 1.335 & 1.353 \\
\hline N11-C10 & - & $\begin{array}{l}1.390 \\
1.376\end{array}$ & 1.362 & 1.341 & 1.343 & - & 1.374 & 1.354 & 1.373 \\
\hline Pd-N3 & - & $\begin{array}{l}1.376 \\
1367\end{array}$ & - & - & - & 2.025 & 2.186 & 2.198 & 2.187 \\
\hline Pd-N11 & - & $\begin{array}{l}1.367 \\
1.379\end{array}$ & - & - & - & 2.054 & 2.194 & 2.200 & 2.195 \\
\hline Pd-C11 & - & $\begin{array}{l}1.379 \\
1332\end{array}$ & - & - & - & 2.2845 & 2.426 & 2.334 & 2.426 \\
\hline $\mathrm{Pd}-\mathrm{Cl} 2$ & - & $\begin{array}{l}1.332 \\
1.337\end{array}$ & - & - & - & 2.2937 & 2.432 & 2.388 & 2.432 \\
\hline gB.A( $\left(^{\circ}\right)$ & & - & & & & & & & \\
\hline N3-Pd-N11 & - & - & - & - & - & 80.22 & 76.7 & 75.9 & 76.6 \\
\hline N3-Pd-Cl1 & - & - & - & - & - & 96.58 & 98.6 & 99 & 98.6 \\
\hline N11-Pd-Cl2 & - & - & - & - & - & 93.75 & 94.9 & 94.9 & 94.9 \\
\hline N3-Pd-Cl2 & - & & - & - & - & 173.50 & 171.5 & 170.9 & 171.5 \\
\hline N11-Pd-Cl1 & - & & - & - & - & 176.36 & 175.3 & 174.9 & 175.3 \\
\hline $\mathrm{C} 11-\mathrm{Pd}-\mathrm{Cl} 2$ & - & - & - & - & - & 89.52 & 89.9 & 90.2 & 89.9 \\
\hline N1-C2-N3 & 112.7 & - & 112.1 & 112.7 & 112.2 & - & 110.6 & 111.4 & 110.6 \\
\hline $\mathrm{C} 2-\mathrm{N} 3-\mathrm{C} 9$ & 106.3 & - & 104.7 & 104.8 & 105.2 & - & 106.8 & 106.3 & 106.8 \\
\hline N3-C9-C8 & 107.6 & - & 110.9 & 110.9 & 110.7 & - & 108.8 & 109.1 & 108.8 \\
\hline $\mathrm{N} 1-\mathrm{C} 8-\mathrm{C} 9$ & 107.2 & - & 104.6 & 104.4 & 104.3 & - & 105.6 & 105.3 & 105.6 \\
\hline $\mathrm{C} 9-\mathrm{C} 4-\mathrm{C} 5$ & 118.2 & 1217 & 116.5 & 116.6 & 117.1 & - & 115.8 & 115.9 & 115.8 \\
\hline $\mathrm{C} 4-\mathrm{C} 5-\mathrm{C} 6$ & 121.9 & 121.7 & 123.2 & 123.4 & 122.9 & - & 123.7 & 123.9 & 123.7 \\
\hline $\mathrm{C} 5-\mathrm{C} 6-\mathrm{C} 7$ & 120.7 & $\begin{array}{l}119.9 \\
1189\end{array}$ & 120.3 & 120.3 & 120.4 & - & 120.3 & 120.3 & 120.3 \\
\hline C6-C7-C8 & 117.6 & $\begin{array}{l}118.9 \\
1185\end{array}$ & 117 & 116.8 & 117 & - & 116.8 & 116.5 & 116.8 \\
\hline C8-C9-C4 & 122.1 & 118.5 & 120.6 & 120 & 119.8 & - & 121 & 120.5 & 121 \\
\hline $\mathrm{N} 11-\mathrm{C} 12-\mathrm{C} 13$ & - & & 123.3 & 118.2 & 124.2 & - & 121.5 & 122.3 & 121.6 \\
\hline C12-C13-C14 & - & & 118.6 & 118.2 & 117.9 & - & 119.4 & 119.1 & 119.4 \\
\hline C13-C14-C15 & - & & 119 & 118.8 & 118.8 & - & 119.2 & 118.9 & 119.2 \\
\hline C14-C15-C10 & - & & 118.8 & 118.7 & 119 & - & 119 & 119 & 119 \\
\hline C15-C10-N11 & 123.0 & & 122.7 & 123.0 & 122.3 & - & 121.3 & 121.8 & 121.3 \\
\hline
\end{tabular}

${ }^{\mathrm{a}}$ npbi: 5-nitro-2-(pyridin-2-yl)-1H-benzo[d]imidazole; ${ }^{\mathrm{b}} \mathrm{mb}$ : 2-methylbenzim idazole; ${ }^{\mathrm{c}}$ pic: 2-picoline,${ }^{\mathrm{d}} \mathrm{Pd}(\mathrm{n})$ : $\operatorname{cis}-\left[\mathrm{Pd}(\mathrm{npbi}) \mathrm{Cl}{ }_{2}\right] ;{ }^{\mathrm{e}} \mathrm{Pd}(\mathrm{p})$ : cis-[Pd(npbi)Cl ${ }_{2}$; ${ }^{\mathrm{f}}$ B.L.: bond Length; ${ }^{\mathrm{g}} \mathrm{B}$.A.: Bond angles. 


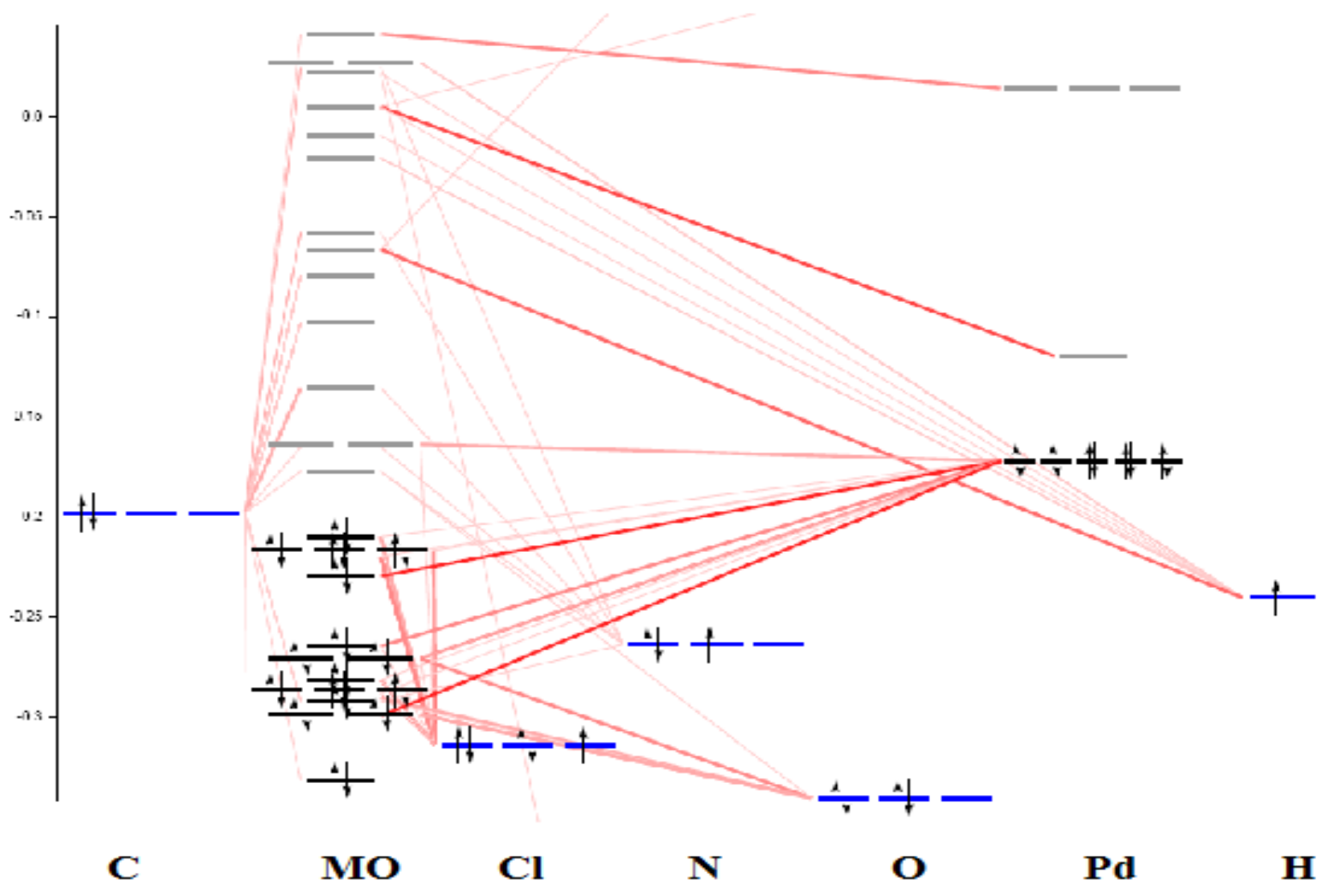

Figure 2. MO diagram of energy for $\left[\mathrm{Pd}(\mathrm{npbi}) \mathrm{Cl}_{2}\right]$ complex, calculated at OLYP level and DZ basis set.

Considering the initial orbital contributions in final molecular orbitales are interesting. Some selected orbitales with related

Table 2. Selective orbitales with QCC,E(e.v), and elements percent for [Pd(npbi)C12] complex, calculated at OLYP level and DZ basis set contributions and occupations, QCC, are shown in Table 2.

\begin{tabular}{|c|c|c|c|c|c|c|c|}
\hline orbital & QCC & $\mathrm{E}(\mathrm{e} . \mathrm{v})$ & $\mathrm{C} \%$ & $\mathrm{~N} \%$ & $\mathrm{O} \%$ & $\mathrm{Cl} \%$ & $\mathrm{Pd} \%$ \\
\hline $54 \mathrm{~A}$ & 2 & -6.010 & - & - & - & $72.51 \mathrm{Pz}$ & $\begin{array}{l}19.92 \mathrm{dyz} \\
+1.87 \mathrm{Pz}\end{array}$ \\
\hline $55 \mathrm{~A}$ & 2 & -5.914 & - & - & - & $\begin{array}{c}58.65 \mathrm{Py} \\
+26.22 \mathrm{Px}\end{array}$ & $9.87 \mathrm{~d} \times 2-\mathrm{y} 2$ \\
\hline $56 \mathrm{~A}$ & 2 & -5.763 & - & - & - & $77.66 \mathrm{Pz}$ & $20.13 d x y$ \\
\hline $57 \mathrm{~A}$ & 0 & -4.840 & $37.44 \mathrm{Pz}$ & $27.82 \mathrm{Pz}$ & $24.53 \mathrm{Pz}$ & - & $1.65 \mathrm{dyz}$ \\
\hline $58 \mathrm{~A}$ & 0 & -4.517 & - & $\begin{array}{c}5.76 \mathrm{Py} \\
+4.19 \mathrm{~S} \\
+1.89 \mathrm{Px}\end{array}$ & - & $\begin{array}{l}25.31 \mathrm{Px} \\
+16.2 \mathrm{Py}\end{array}$ & $\begin{array}{c}39.51 \mathrm{dxy} \\
+2.50 \\
\mathrm{dx} 2-\mathrm{y} 2\end{array}$ \\
\hline $59 \mathrm{~A}$ & 0 & -4.512 & $52.57 \mathrm{Pz}$ & $30.12 \mathrm{Pz}$ & $6.4 \mathrm{Pz}$ & - & $\begin{array}{c}1.38 \mathrm{dyz} \\
+1.15 \mathrm{dxy}\end{array}$ \\
\hline
\end{tabular}


As one can see, the HOMO and LUMO are 56A and 57A orbital respectively. The $\mathrm{P}_{\mathrm{z}}$ orbital of chloride atoms has the most contribution, $77.66 \%$, for $\mathrm{HOMO}$ while the next atomic orbital is $\mathrm{P}_{\mathrm{z}}$ of palladium, 20.13\%. This fact is shown in Fig. 3 ., obtained from the calculation. Basis to our calculations, none of the chloride atoms orbital have a contribution in LUMO or 57A. Instead, $\mathrm{P}_{\mathrm{z}}$ of carbon, nitrogen, oxygen has the most contribution, $37.44 \%, 27.82 \%$, and $24.53 \%$ respectively in LUMO or 57A. The $\mathrm{d}_{\mathrm{xz}}$ of palladium has just $1.65 \%$ contribution here.

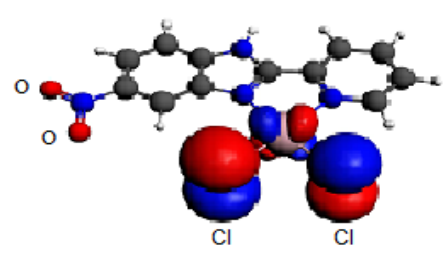

HOMO

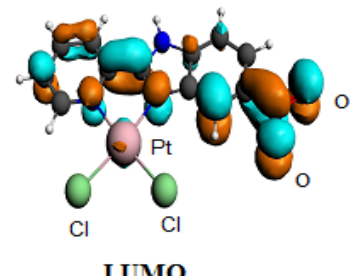

LUMO
Figure 3. HOMO and LUMO orbitales of $\left[\mathrm{Pd}(\mathrm{npbi}) \mathrm{Cl}_{2}\right]$ complex, calculated at OLYP level and DZ basis set.

\subsubsection{Vibrational Spectroscopy}

The npbi ligand and its $\mathrm{Pd}(\mathrm{II})$ complex are characterized with FTIR spectroscopy. Furthermore, their harmonic vibrational frequencies computed at the OLYP method and various mentioned basis sets. The selected calculated frequencies and experimental values are listed in Table 3.

When the IR spectra of the free npbi ligand and its $\mathrm{Pd}(\mathrm{II})$ complex are compared, some interesting facts could be obtained. There is a broad band in the region $3070.5 \mathrm{~cm}^{-1}$ in the IR spectrum of ligand that is shifted to $3093.6 \mathrm{~cm}^{-1}$ when coordination occurred. This fact could be due to the intermolecular tautomerism of ligand in imidazole $\mathrm{N}-\mathrm{H}$ bond. The related N-H stretching in the Pd(II) complex at $3093.6 \mathrm{~cm}^{-1}$, is sharper than the ligand due to the breaking of tautomerism, indicating the imidazole $\mathrm{N}-\mathrm{H}$ is not involved in the coordination $[21,22]$.

The band in the region $1610 \mathrm{~cm}^{-1}$ of the free ligand assigned to $\mathrm{C}=\mathrm{N}$ stretching of imidazole. This stretching is shifted to just a little more frequency, $1612.4 \mathrm{~cm}^{-1}$, after complexation $[23,24]$. This fact is confirmed the breaking of tautomerism again.

The difference between the $\mathrm{C}=\mathrm{N}$ stretching of pyridine in free ligand, $1596.9 \mathrm{~cm}^{-1}$, and complex, $1490 \mathrm{~cm}^{-1}$, is suggested the interaction between the related nitrogen and palladium center. Our calculation is confirmed this advantage and the $1588 \mathrm{~cm}^{-1}$ band is shifted to $1546 \mathrm{~cm}^{-1}$. There are two bands in the far-IR region of the calculated spectrum of Pd(II) complex, $229 \mathrm{~cm}^{-1}$ and $238 \mathrm{~cm}^{-1}$, which we assigned theoretically to symmetrical an asymmetrical stretching of $\mathrm{Pd}-\mathrm{Cl}$ bond respectively. The $\mathrm{Pd}-\mathrm{N}_{\mathrm{py}}$ stretching is obtained at $418 \mathrm{~cm}^{-1}$ based on our calculation. This frequency is reported at $495 \mathrm{~cm}^{-1}[25]$.The other experimental and calculated frequencies for both free ligand and its palladium complex are collected in Table 3 .

Table 3. Selected experimental and calculated IR vibrational frequencies $\left(\mathrm{cm}^{-1}\right)$ of the npbi ligand and $\left[\mathrm{Pd}(\mathrm{npbi}) \mathrm{Cl}_{2}\right]$ complex

\begin{tabular}{|c|c|c|c|c|}
\hline \multicolumn{2}{|c|}{ Experimental frequencies } & \multicolumn{2}{|c|}{ Calculated frequencies } & \multirow{2}{*}{$\begin{array}{l}\text { Vibrational } \\
\text { assignment }\end{array}$} \\
\hline Ligand & Pd(II) Complex & Ligand & Pd(II) Complex & \\
\hline 3070.5 & 3093.6 & 3567 & 3585 & $\boldsymbol{v}(\mathrm{N}-\mathrm{H})_{\operatorname{Imi}}$ \\
\hline 2951.6 & 2923.9 & 3210 & 3209 & $v_{\mathrm{S}}(\mathrm{C}-\mathrm{H})_{\mathrm{BZ}}$ \\
\hline 2854.5 & 2854.5 & 3204 & 3203 & $v_{\text {as }}(C-H)_{\text {BZ }}$ \\
\hline- & - & 1605 & 1609 & $\mathrm{v}(\mathrm{C}=\mathrm{C})_{\mathrm{BZ}}$ \\
\hline 1610 & 1612.4 & 1514 & 1602 & $v(\mathrm{C}=\mathrm{N})_{\text {Imi }}$ \\
\hline 1596.9 & 1490 & 1588 & 1546 & $v(\mathrm{C}=\mathrm{N})_{\mathrm{PY}}$ \\
\hline- & - & 1578 & 1572 & $v(C-C)_{P Y}$ \\
\hline 1512.1 & 1519.8 & 1577 & 1609 & $\mathrm{v}_{\mathrm{as}}\left(\mathrm{NO}_{2}\right)$ \\
\hline 1442.7 & 1450.4 & 1479 & 1425 & $v(\mathrm{C}=\mathrm{C})_{\mathrm{BZ}}$ \\
\hline- & - & 1464 & - & $v(\mathrm{C}-\mathrm{C}, \mathrm{C}-\mathrm{H})_{\mathrm{PY}}$ \\
\hline- & - & 1418 & 1458 & $\delta_{\mathrm{twi}}(\mathrm{C}-\mathrm{H})_{\mathrm{PY}}$ \\
\hline- & - & 1416 & 1410 & $\delta_{\text {twi }}(\mathrm{N}-\mathrm{H})$ \\
\hline 1334.6 & 1334.6 & 1332 & 1327 & $v\left(\mathrm{C}-\mathrm{NO}_{2}\right)$ \\
\hline- & - & 1321 & 1425 & $v(C-C)_{B Z}$ \\
\hline- & - & - & 1060 & $v\left(\mathrm{Pd}-\mathrm{N}_{\mathrm{Imi}}\right)$ \\
\hline 1056.9 & 1072.3 & 1056 & - & $\delta_{\mathrm{roc}}(\mathrm{C}-\mathrm{C})_{\mathrm{BZ}}$ \\
\hline- & - & 1049 & 1052 & $\delta_{\text {roc }}(\mathrm{C}-\mathrm{C})_{\mathrm{PY}}$ \\
\hline- & 987.5 & 876 & 791 & $\delta_{\text {ip }}(\mathrm{C}-\mathrm{H})_{\mathrm{BZ}}$ \\
\hline- & 894.9 & 871 & 779 & $\delta_{\mathrm{ip}}(\mathrm{C}-\mathrm{H})_{\mathrm{PY}}$ \\
\hline- & 825.5 & 844 & 829 & $\delta_{\mathrm{BZ}}$ \\
\hline 740.6 & 786.9 & 793 & 764 & $\delta_{\mathrm{OP}}(\mathrm{C}-\mathrm{H})_{\mathrm{BZ}}$ \\
\hline- & 740.5 & 727 & 718 & $\delta_{\mathrm{OP}}(\mathrm{C}-\mathrm{H})_{\mathrm{PY}}$ \\
\hline 624.9 & 524.6 & - & - & $\delta_{\mathrm{PY}}$ \\
\hline- & - & 557 & 510 & $\delta_{\text {roc }}(\text { rig })_{\mathrm{BZ}}$ \\
\hline- & 432 & 476 & 492 & $\delta_{\text {ip }}(\mathrm{N}-\mathrm{H})$ \\
\hline - & - & - & 418 & $v\left(\mathrm{Pd}-\mathrm{N}_{\mathrm{PY}}\right)$ \\
\hline - & - & - & 229 & $v_{\mathrm{S}}(\mathrm{Pd}-\mathrm{Cl})$ \\
\hline & - & - & 238 & $v_{\text {as }}(\mathrm{Pd}-\mathrm{Cl})$ \\
\hline
\end{tabular}

Vibrational modes: $v$, stretching; $\delta$, bending; op, out-of-plane; ip, in-plane; roc, rocking; twi, twisting; s, symmetric; as, anti-symmetric. 


\section{Acknowledgements}

We gratefully acknowledge the support of this work by the Payame Noor University Research Council. We are also grateful to Mr. S.Y. Ebrahimi, Mr. M. Ahmadi, Mis Z. Alinia and Mis. S. Shariati for their helpful cooperation.

\section{REFERENCES}

[1] A. Garoufis, S.K. Hadjikakou and N. Hadjiliadis, Coord. Chem. Rev. 2539 (2009) 1384-1397

[2] S. Mukherjee, S. Chowdhury, A. P. Chattapadhyay, A. Bhattacharya, Inorg. Chim. Acta, 373 (2011) 40-46

[3] N. T. Abdel Ghani, A. M. Mansour, Inorganica Chimica Acta, 373 (2011) 249-258

[4] M. Juribašić, K. Molčanov, B. Kojić-Prodić, L. Bellotto, M. Kralj, F. Zani, L. TušekBožić, J. Inorg. Biochem., 105 (2011) 867-879

[5] E.Budzisz, Pol.J.Cosm.9 (2006) 212-221.

[6] A. V. G. Netto, R. C.G. Frem, A. E. Mauro, R. H.A. Santos and J. R. Zoia, Transit. Metal Chem., 27 (2002) 279-283

[7] A. V. G. Netto, , P. M. Takahashi, R. C. G. Frem, A. E. Mauro, and H. E. Zorel Júnior.J. Anal Appl. Pyrol., 72 (2004) 183-189

[8] A. Fernández et.al, Inorganica Chimica Acta, 370 (2011) 89-97

[9] N. A. Anan, Sh. M. Hassan, E. M. Saad, I. S. Butler, S. I. Mostafa, Carbohydrate Research, 346 (2011) 775-793

[10] Ying He, Chun Cai, Catalysis Communications, 12 (2011) 678-683
[11] M. Sönmez, M. Çelebi, Y. Yardım, Z. Şentürk, Eur. J. Med. Chem., 45 (2010) 4215-4220

[12] A. S. Mocanu, M. Iliş, F. Dumitraşcu, M. Ilie, V. Cîrcu, Inorganica Chimica Acta, 363 (2010) 729-736

[13] H. Sharghi, M. Aberi, and M. M. Doroodmand, Adv. Synth. Catal. (2008), 350, 2380-2390

[14] H. Sharghi, O. Asemani, and R. Khalifeh, Synthetic Communications, 38, (2008), 1128-1136

[15] A.E. Obodovskaya, Z.A. Starikova, S.N. Belous, I.E. Pokrovskaya, J. Struct. Chem.

[16] 32 (1991) 421.

[17] I.I.Vorontsov,L.Almásy, M.Yu.Antripin, J.Mol.Struct.610 (2002) 271.

[18] A.E.Obodovskaya,, Z.A.Starikova, S.N.Belous,,I.E.Pokrovsk aya, J.Struct.Chem. 32 (1991) 421.

[19] J.S. Casas, E. E. Castellano, A. Macias, M. C. Rodr1guez-Arguelles, Ez. A. Sanc and J. Sordo ,.J. Chemistry Society Dalton Trans Dalton Commun. 2 , (1993); 353

[20] A.K.El.Sawaf,D.X.West,F.A.El-Saied R.M.El-Behnesawy,Trans ,Met Chem.23 (1998) 649-655

[21] D.J.Rabiger and M.M.Joullie ,J.Org.Chem .29 (1964) 476-482

[22] R.C.Maurya and D.D.Mishra, Synth.React.Inorg.Met.Org.C hem.20 (1990) 1013

[23] L.J.Baocher and J.C.Bailor .J.Inorg.Nucl.Chem.27 (1965) 1093-1099

[24] R.L.Dutta and S.K.Satapathi,J.Inorg.Nucl.Chem.43 (1981) 1533-1539

[25] E.Budzisz, M.A.Miernicka, I.P.Lorenz, P.Mayer, U.Krajewska, M.Rozalski, Polyhedron. 28 (2009) 637-645 